\title{
Anticitrullinated Protein Antibody, But Not Its Titer, Is a Predictor of Radiographic Progression and Disease Activity in Rheumatoid Arthritis
}

\author{
KAZUKO SHIOZAWA, YOSHIKO KAWASAKI, TAKASHI YAMANE, RYOSUKE YOSHIHARA, YASUSHI TANAKA, \\ KENICHI UTO, and SHUNICHI SHIOZAWA
}

ABSTRACT. Objective. To study the contribution of anticitrullinated protein antibody (ACPA), and especially of its titer, to radiographic progression and disease activity in rheumatoid arthritis (RA).

Methods. Patients with RA $(n=396)$ who attended a Japanese clinic within 2 years after disease onset were divided into the following groups according to second-generation (ACPA-2) ACPA titer on their first visit: negative $(0-4.4 \mathrm{U} / \mathrm{ml} ; \mathrm{n}=115)$, low-positive $(4.5-121 \mathrm{U} / \mathrm{ml} ; \mathrm{n}=141)$, and high-positive $(>121 \mathrm{U} / \mathrm{ml} ; \mathrm{n}=140)$. The ACPA-2-positive groups were further subdivided into lowest $(4.5-32 \mathrm{U} / \mathrm{ml})$, low (33-121 U/ml), high (122-277 U/ml), and highest (> $278 \mathrm{U} / \mathrm{ml})$ quartiles. All patients were treated with disease-modifying antirheumatic drugs (DMARD) including methotrexate, but not biologics. Subsequent radiographic progression and disease activity for 2 years were prospectively evaluated using the van der Heijde-modified Sharp score (SHS) and 28-joint Disease Activity Score (DAS28). Results. After treatment with DMARD, the disease activity (including number of swollen joints, number of tender joints, duration of morning stiffness, DAS28-erythrocyte sedimentation rate, and DAS28-C-reactive protein) was significantly decreased in all patient groups. Disease activity and radiographic progression as revealed by the change in SHS remained relatively higher in the ACPA-2 low- and high-positive groups as compared with the ACPA-2-negative group. The relationship between the titer of ACPA-2 at baseline and subsequent radiographic progression was not exactly linear, and the extent of disease activity or radiographic progression was similar between ACPA-2 low- and high-positive groups and also between ACPA-2 lowest- and highest-positive quartile groups. The results were demonstrable in cumulative SHS probability plots, and also repeatable in seronegative patients, which indicated that the titer of ACPA-2 is not a predictor of disease activity or radiographic progression in RA, and ACPA-2-negative patients, especially those with $<3 \mathrm{U} / \mathrm{ml}$, showed minimal radiographic progression. Conclusion. Presence of ACPA-2, but not its titer, at baseline is a predictor of radiographic progression or disease activity, where radiographic progression is minimal in ACPA-2-negative patients. (First Release March 1 2012; J Rheumatol 2012;39:694-700; doi:10.3899/jrheum.111152)

Key Indexing Terms:

RHEUMATOID ARTHRITIS

DISEASE ACTIVITY

\section{ANTICITRULLINATED PROTEIN ANTIBODIES RADIOGRAPHIC PROGRESSION}

From the Rheumatic Diseases Center, Konan Kakogawa Hospital, Kakogawa; the Department of Medicine and the Center for Rheumatic Diseases, Kobe University Graduate School of Medicine and Hospital, Kobe; Global Center of Excellence (GCOE), Japan.

K. Shiozawa, MD, PhD, Rheumatic Diseases Center, Konan Kakogawa Hospital; Y. Kawasaki, MD, Department of Medicine and the Center for Rheumatic Diseases, Kobe University Graduate School of Medicine and Hospital; T. Yamane, MD, PhD; R. Yoshihara, MD, PhD; Y. Tanaka, MD PhD, Rheumatic Diseases Center, Konan Kakogawa Hospital; K. Uto, PhD, Department of Medicine and the Center for Rheumatic Diseases, Kobe University Graduate School of Medicine and Hospital; S. Shiozawa, $M D, P h D$, Department of Medicine and the Center for Rheumatic Diseases, Kobe University Graduate School of Medicine and Hospital, Department of Medicine, Kyushu University, Beppu Hospital, and Investigator of the GCOE.

Dr. Shiozawa and Dr. Kawasaki contributed equally to this report. Address correspondence to Prof. S. Shiozawa, Department of Medicine, Kyushu University, Beppu Hospital, Tsurumihara, Верри 874-0838, Japan.E-mail: shiozawa@beppu.kyushu-u.ac.jp

Accepted for publication November 22, 2011.
Anticitrullinated protein antibodies (ACPA) hold promise for earlier and more accurate diagnosis of rheumatoid arthritis (RA) and are expected to improve prognostic information in $\mathrm{RA}^{1,2,3}$. Studies have shown that the presence of ACPA predicts a greater radiographic progression $4,5,6,7,8,9,10,11,12,13$ and possibly a less favorable disease course ${ }^{13,14,15}$ and consequently, ACPA and rheumatoid factor (RF) have been incorporated into recent European League Against Rheumatism/ American College of Rheumatology (ACR) classification criteria $^{16}$. However, studies to date suggest that clinical features of RA, including distribution of affected joints, swollen joints, bone erosions, and joint space narrowing ${ }^{13}$, or the remission rates for a relatively longer $3-5$-year period ${ }^{17}$ were similar between the patients with and those without ACPA. One study also shows that the titer of ACPA predicts the disease activity of male patients only ${ }^{18}$. Another study shows that the extent of 
Table 1. Baseline profile of patients with rheumatoid arthritis.

\begin{tabular}{|c|c|c|c|c|c|c|}
\hline Characteristic & $\begin{array}{l}\text { Negative Group, } \\
\text { ACPA } 0-4.4 \mathrm{U} / \mathrm{ml}\end{array}$ & $\begin{array}{c}\text { Low Group, } \\
\text { ACPA 4.5-121 U/ml }\end{array}$ & $\begin{array}{c}\text { High Group, } \\
\text { ACPA }>122 \mathrm{U} / \mathrm{ml}\end{array}$ & $\begin{array}{c}\mathrm{p}, \\
\text { Negative vs Low }\end{array}$ & $\begin{array}{c}\mathrm{p}, \\
\text { Negative vs High }\end{array}$ & $\begin{array}{c}\mathrm{p}, \\
\text { Low vs High }\end{array}$ \\
\hline ACPA-2 antibody titer, $\mathrm{U} / \mathrm{ml}$ & $0.6 \pm 1.1$ & $47.1 \pm 34.2$ & $462.5 \pm 440.3$ & & & \\
\hline Female, $\%$ & 72.2 & 79.4 & 72.1 & NS & NS & NS \\
\hline Age of onset, yrs, mean \pm SD & $58.5 \pm 14.6$ & $53.8 \pm 13.5$ & $57.1 \pm 12.7$ & 0.005 & NS & NS \\
\hline Age of first visit, yrs, mean \pm SD & $59.2 \pm 14.4$ & $54.5 \pm 13.3$ & $58.0 \pm 12.6$ & 0.006 & NS & NS \\
\hline $\mathrm{ESR}, \mathrm{mm} / \mathrm{h}$ & $57 \pm 37$ & $55 \pm 34$ & $58 \pm 34$ & NS & NS & NS \\
\hline $\mathrm{CRP}, \mathrm{mg} / \mathrm{dl}$ & $2.8 \pm 3.6$ & $2.3 \pm 3.2$ & $2.2 \pm 2.8$ & NS & NS & NS \\
\hline MMP-3, ng/ml & $204 \pm 301$ & $210 \pm 281$ & $161 \pm 155$ & NS & NS & NS \\
\hline No. swollen joints & $9 \pm 8$ & $9 \pm 7$ & $9 \pm 7$ & NS & NS & NS \\
\hline No. tender joints & $9 \pm 8$ & $8 \pm 6$ & $8 \pm 7$ & NS & NS & NS \\
\hline Grip strength, $\mathrm{mm} \mathrm{Hg}$ & $179 \pm 79$ & $186 \pm 74$ & $190 \pm 74$ & NS & NS & NS \\
\hline Sharp score (erosion) & $1.0(0.0,3.0)$ & $2.0(1.0,8.0)$ & $3.0(1.0,8.0)$ & 0.002 & 0.00001 & NS \\
\hline Sharp score (total) & $3.0(1.0,6.0)$ & $5.0(2.0,14.0)$ & $6.0(3.0,14.5)$ & 0.002 & 0.00001 & NS \\
\hline
\end{tabular}

ACPA: anticitrullinated protein antibody; RF: rheumatoid factor; ESR: erythrocyte sedimentation rate; CRP: C-reactive protein; MMP-3: matrix metalloproteinase 3; DAS28: 28-joint Disease Activity Score.

radiographic progression in the ACPA-negative patients may be comparable to those of ACPA-positive patients ${ }^{19}$. Thus, the attribute of ACPA in relation to radiographic progression and/or disease activity remains unclear in $\mathrm{RA}^{12,20,21,22,23}$.

We have studied whether the titer of ACPA can be a predictor of radiographic progression and/or disease activity in Japanese patients with RA $(n=396)$ who visited our hospital within 2 years after onset to clarify the clinical characteristics of ACPA in relation to the prognosis, i.e., disease activity and radiographic progression.

\section{MATERIALS AND METHODS}

Serum second-generation ACPA (ACPA-2) was measured in 396 patients with RA on their first visit to the Konan Kakogawa Hospital between April 2003 and March 2006. Only the patients who visited within 2 years after disease onset and were found to fulfill the ACR diagnostic criteria ${ }^{24}$ in later disease course were included in the study. We used an ACPA-2 assay widely used in $\mathrm{Japan}^{3}$. Its performance has been proved to be comparable to the third-generation ELISA kits ${ }^{2}$. The patients were treated mostly with methotrexate (MTX) or other disease-modifying antirheumatic drugs (DMARD) and/or daily prednisolone $\leq 5 \mathrm{mg}$ (Table 1 ). Patients were followed prospectively for 2 years. Patients treated with anti-tumor necrosis factor- $\alpha$ biological agents were not included in our study because the use of biologics was not common between 2003 and 2006 in Japan. The patients were divided according to ACPA-2 titer on their first visit (baseline) into a negative group $(0-4.4 \mathrm{U} / \mathrm{ml} ; \mathrm{n}=115)$ and low-positive $(4.5-121 \mathrm{U} / \mathrm{ml} ; \mathrm{n}=141)$ and high-positive $(>121 \mathrm{U} / \mathrm{ml} ; \mathrm{n}=140)$ groups. The low- and high-positive groups were divided by referring to the median value, $121 \mathrm{U} / \mathrm{ml}$. The ACPA-2-positive groups were further subdivided into lowest (4.5-32 U/ml; n = 70), low (33-121 U/ml; $\mathrm{n}=71)$, high $(122-277 \mathrm{U} / \mathrm{ml} ; \mathrm{n}=70)$, and highest $(>278 \mathrm{U} / \mathrm{m} ; \mathrm{n}=70$ ) positive quartiles. Lowest- and highest-positive quartile groups were then compared. The clinical features and disease activities were assessed using disease activity scores including a 28-joint Disease Activity Score (DAS28)-erythrocyte sedimentation rate (ESR) [DAS28-ESR (3)] and DAS28-C-reactive protein (CRP) [DAS28-CRP (3)], laboratory measures of
ESR, rheumatoid factor (RF), CRP, or matrix metalloproteinase 3 (MMP-3), and hand radiographic evaluation performed using van der Heijde-modified Sharp score (SHS), with a range of 0-306 (narrowing + erosion) ${ }^{25}$, and expressed as annual change from baseline between 0 and 48 weeks. To evaluate the independence of ACPA as a predictor of radiographic progression, we also identified RF-negative patients $(\mathrm{n}=127)$ and assessed their radiographs.

Statistical analyses were performed using the MedCalc system (MedCalc Software bvba, Mariakerke, Belgium). Data were expressed as the mean \pm SD or median with interquartile range. All statistical tests were 2-sided and were performed at an $\alpha$ level of 0.05 . Differences between groups were assessed using the parametric Student's t-test or 1-way ANOVA. When distribution of the data was skewed, differences between groups were assessed using the nonparametric Mann-Whitney U test or the Kruskal-Wallis test. Categorical variables were assessed using chi-square test.

\section{RESULTS}

We divided patients with RA into 3 groups according to the titer of ACPA at baseline: negative $(0-4.4 \mathrm{U} / \mathrm{ml})$, low-positive (4.5-121 U/ml), and high-positive $(>121 \mathrm{U} / \mathrm{ml})$. We found that RF and SHS at baseline were relatively higher in the ACPA low-positive and high-positive groups as compared with the negative group (Table 1), suggesting that joint destruction might have been faster in the ACPA-2-positive groups in the period before visiting the hospital, because the patients' disease durations were similar.

It was noted that the relationship between the titer of ACPA-2 at baseline and subsequent radiographic progression was more or less variable and not exactly linear; however, radiographic progression of ACPA-2-negative patients, especially those with $<3 \mathrm{U} / \mathrm{ml}$, was minimal (Figure 1).

All patients were treated with DMARD including MTX, but not biologics (Table 2). After treatment, the data for ESR, CRP and MMP- 3 in sera, number of swollen joints, number of tender joints, duration of morning stiffness, DAS28-ESR (3), 


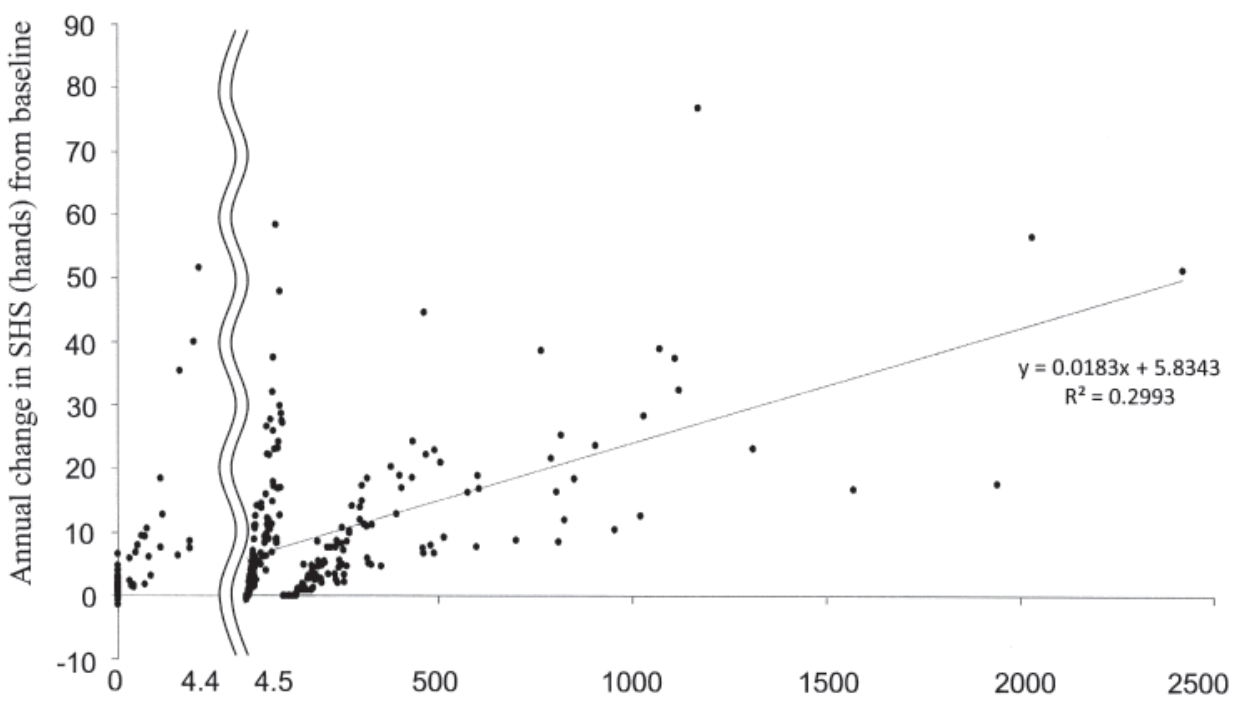

Anti-CCP2 antibody $(\mathrm{U} / \mathrm{mL})$

Figure 1. Relationship between the titer of ACPA-2 and the annual change in van der Heijde-modified Sharp score (SHS) of hands from baseline. Note that radiographic progression in ACPA-2-negative patients, especially those with $<3 \mathrm{U} / \mathrm{ml}$, was minimal.

Table 2. Profile of patients with RA at 2-year followup. Mean \pm SD or median (interquartile range) unless otherwise specified.

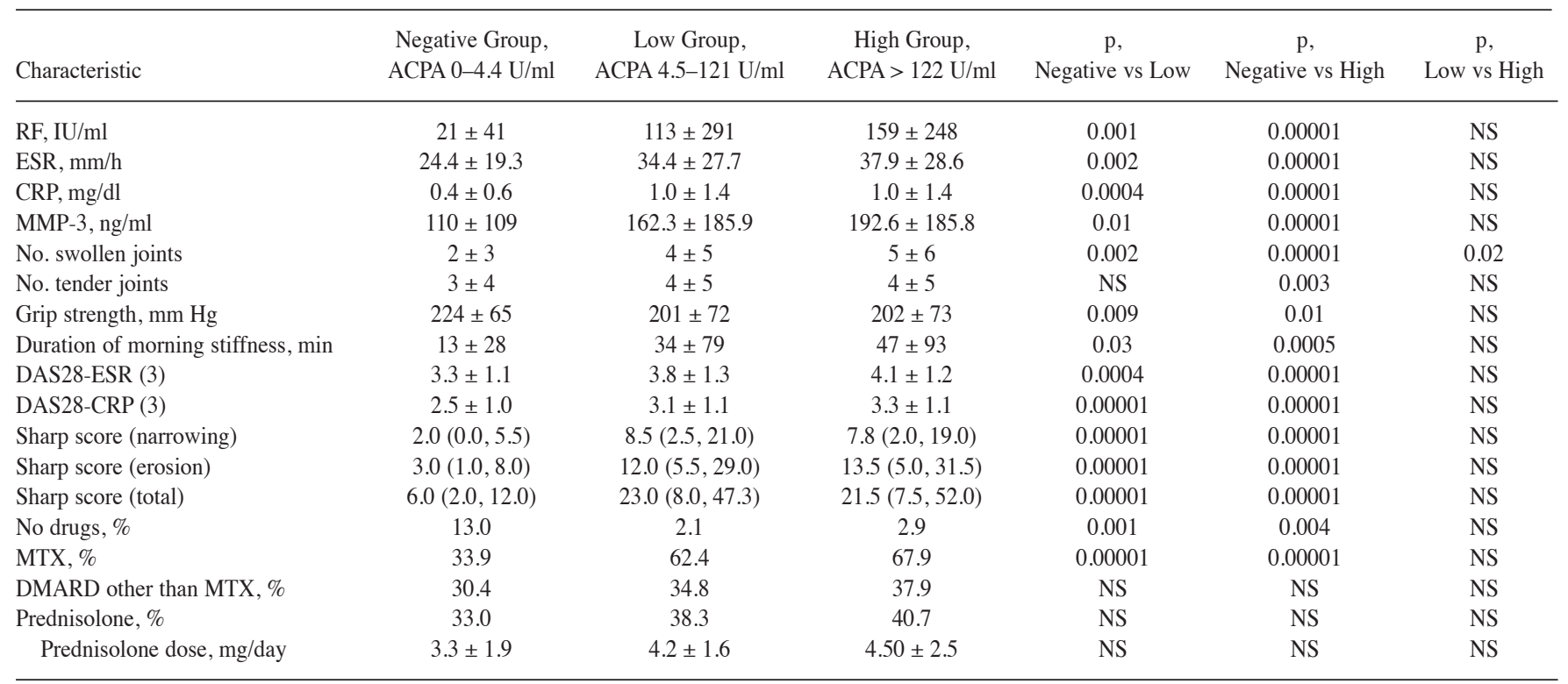

NS: not significant; ACPA: anticitrullinated protein antibody; RF: rheumatoid factor; ESR: erythrocyte sedimentation rate; CRP: C-reactive protein; MMP-3: matrix metalloproteinase 3; DAS28: 28-joint Disease Activity Score; DMARD: disease-modifying drugs; MTX: methotrexate.

and DAS28-CRP (3) were all significantly improved in the ACPA-2-negative group (Table 2). It was noted that CRP, number of swollen joints, number of tender joints, duration of morning stiffness, DAS28-ESR (3), and DAS28-CRP (3) remained relatively higher in the ACPA-2 low-positive and high-positive groups (Table 2), indicating that the patients with negative ACPA- 2 had less active disease. Thus, while the presence or absence of ACPA-2 at baseline predicts disease outcome of RA, the titer of ACPA-2 at baseline appeared not to predict disease activity significantly.

With regard to joint destruction, SHS was significantly increased in the ACPA-2 low-positive and high-positive groups after 2 years of treatment (Tables 1 and 2). However, the extent of annual change in SHS with regard to joint narrowing, erosion, and total score was similar between ACPA-2 low-positive and high-positive groups (Table 2). The change 
in SHS as a cumulative probability plot showed a marked difference between ACPA-2 low- and high-positive groups as compared with the ACPA-negative group (Figure 2). Importantly, there was no difference in the change in SHS between ACPA-2 low-positive and high-positive groups. It thus appears that absence of ACPA-2 at baseline predicts better joint prognosis, whereas the titer of ACPA-2 at baseline itself appears to be irrelevant to radiographic progression (Figure 2).

To confirm these findings, we compared ACPA-2 lowest-positive and highest-positive groups (Tables 3 and 4), with the patients grouped into lowest and highest quartiles. It was again noted that disease activity and radiographic progression were similar between ACPA-2 lowest and highest groups (Tables 3 and 4, Figure 3).

To verify whether ACPA-2 is a predictor of radiographic progression independent of RF, we identified 126 RF-negative patients and assessed their radiographic progression rate. We found that annual change in SHS from baseline was significantly higher in the ACPA-2 low-positive $(n=22)$ and high-positive $(n=19)$ groups as compared to the ACPA-2negative group $(\mathrm{n}=85)$, respectively: $9.9 \pm 10.8$ and $10.0 \pm$ 11.2 versus $3.9 \pm 8.3(\mathrm{p}=0.01$ and $\mathrm{p}=0.018$, respectively). The change in SHS as a cumulative probability plot for RF-negative patients is shown in Figure 4.

\section{DISCUSSION}

The results show that presence of ACPA-2, but not its titer, at baseline is a predictor of radiographic progression and disease activity in RA. The difference in disease activity and radiographic progression between ACPA-2-negative and ACPA-2-positive patients was significant. It was noted that radiographic progression illustrated as a cumulative probability plot was significantly different (Figure 2).
The results showed that radiographic progression of ACPA-2-negative patients, especially those with $<3 \mathrm{U} / \mathrm{ml}$, was minimal (Figure 1). To our knowledge, an exact comparison between the titer of ACPA at baseline and subsequent radiographic progression in a prospective fashion has been made for the first time in our study, and the result showed that the relationship between the titer of ACPA-2 at baseline and radiographic progression was variable and not exactly linear (Figure 1). While the patients who were positive for ACPA-2 had relatively active disease despite treatment with DMARD in this and previous studies ${ }^{26}$, we found that radiographic progression was not always faster in ACPA-positive patients: there are exceptions. This finding is compatible with the previous findings that the effect of ACPA on radiographic progression reaches statistically significant levels only after 3 to $6^{4,7,10,19}$ or even $10^{20}$ years of study: thus, the quantitative contribution of ACPA-2 is not very significant.

As to why ACPA-2 at baseline fails to show an exact linear relationship with radiographic progression, an explanation could be as follows. Our previous study using the largest number of patients with very early onset of RA (67 patients $<3$ months, 120 patients $<6$ months out of 435 patients $<2$ years from disease onset $)^{3}$ showed that, while ACPA-2 alone was highly specific and accurately predicted future development of RA when measured very early, i.e., within 3 months after disease onset, such accuracy was gradually lost when measured beyond 6 months after onset, probably because factors other than ACPA also are associated with the pathogenesis of arthritis $27,28,29$. In our study, the disease duration was between 6 and 10 months (Table 1), and therefore it is reasonable that the titer of ACPA-2 did not correlate exactly with radiographic progression. Taking these findings together, we may con-

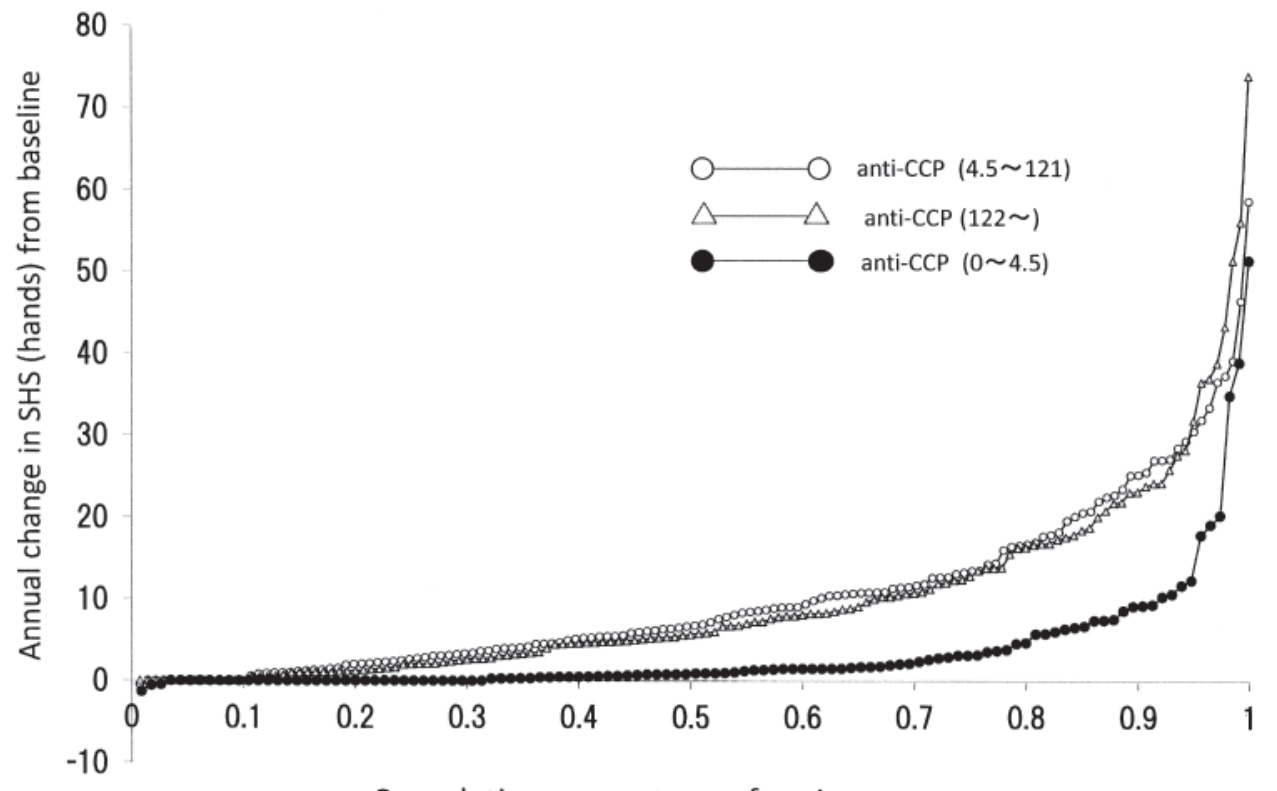

Cumulative percentage of patients

Figure 2. Cumulative probability plot shows annual change in van der Heijde-modified Sharp score (SHS) of hands from baseline, for ACPA-2 titer in all patients with rheumatoid arthritis $(\mathrm{n}=396)$. 
Table 3. Baseline profile of patients with RA, comparing lowest quartile to highest quartile. Data are mean \pm SD or median (interquartile range) unless otherwise specified.

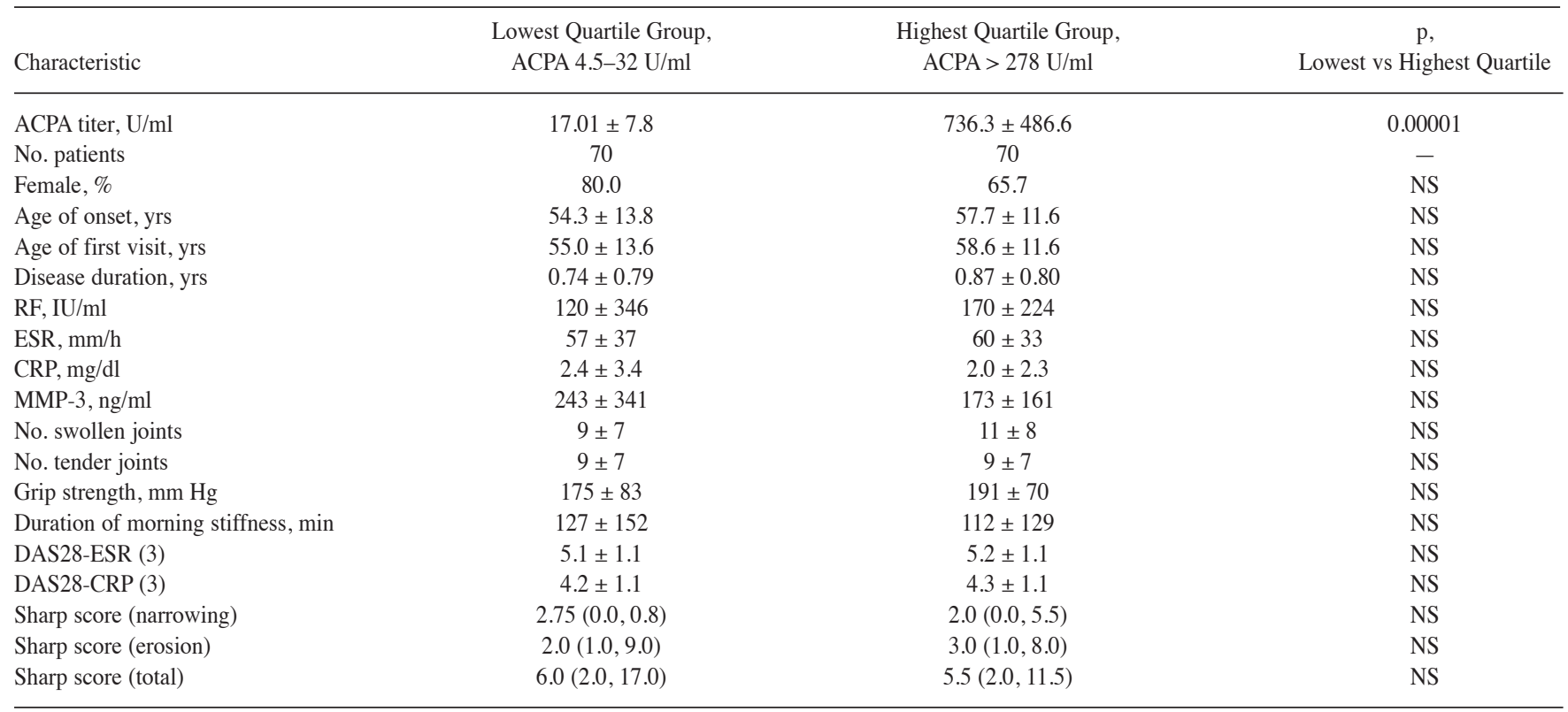

NS: not significant; ACPA: anticitrullinated protein antibody; RF: rheumatoid factor; ESR: erythrocyte sedimentation rate; CRP: C-reactive protein; MMP-3: matrix metalloproteinase 3; DAS28: 28-joint Disease Activity Score.

Table 4. Profile of patients with RA at 2-year followup, comparing lowest quartile to highest quartile. Data are mean \pm SD or median (interquartile range) unless otherwise specified.

\begin{tabular}{lccc}
\hline Characteristic & $\begin{array}{c}\text { Lowest Quartile Group, } \\
\text { ACPA } 4.5-32 \text { U/ml }\end{array}$ & $\begin{array}{c}\text { Highest Quartile Group, } \\
\text { ACPA }>278 \text { U/ml }\end{array}$ & $\begin{array}{c}\text { p, } \\
\text { Lowest vs Highest Quartile }\end{array}$ \\
\hline RF, IU/ml & $120 \pm 346$ & $170 \pm 224$ & NS \\
ESR, mm/h & $34 \pm 29$ & $42 \pm 30$ & NS \\
CRP, mg/dl & $1.0 \pm 1.5$ & $0.9 \pm 1.2$ & NS \\
MMP-3, ng/ml & $163 \pm 179$ & $185 \pm 180$ & NS \\
No. swollen joints & $4 \pm 4$ & $5 \pm 6$ & NS \\
No. tender joints & $4 \pm 5$ & $209 \pm 74$ & NS \\
Grip strength, mm Hg & $193 \pm 73$ & $47 \pm 102$ & NS \\
Duration of morning stiffness, min & $29 \pm 72$ & $4.1 \pm 1.2$ & NS \\
DAS28-ESR (3) & $3.8 \pm 1.3$ & $3.1 \pm 1.2$ & NS \\
DAS28-CRP (3) & $3.1 \pm 1.1$ & $5.0(2.0,18.0)$ & NS \\
Sharp score (narrowing) & $10.0(3.5,24.5)$ & $12.0(5.0,34.0)$ & 0.048 \\
Sharp score (erosion) & $16.0(5.0,27.0)$ & $19.0(6.0,49.5)$ & NS \\
Sharp score (total) & $26.5(11.0,51.5)$ & 1.43 & NS \\
No drugs, $\%$ & 1.43 & 70.00 & NS \\
MTX, $\%$ & 64.38 & 40.00 & NS \\
DMARD other than MTX, & 32.85 & 46.51 & NS \\
Prednisolone, $\%$ & 41.42 & $4.46 \pm 2.98$ & NS \\
$\quad$ Prednisone dose, mg/day & $4.52 \pm 1.61$ & & NS \\
& & & \\
\hline
\end{tabular}

NS: not significant; ACPA: anticitrullinated protein antibody; RF: rheumatoid factor; ESR: erythrocyte sedimentation rate; CRP: C-reactive protein; MMP-3: matrix metalloproteinase 3; DAS28: 28-joint Disease Activity Score; DMARD: disease-modifying drugs; MTX: methotrexate.

clude that radiographic progression is minimal when ACPA is negative; however, radiographic progression is not always faster when the titer of ACPA is high. Further, in our study, serum ACPA was measured more than twice in 41 of 115 ACPA-negative patients. The result showed that ACPA-2 was consistently negative in all 41 patients. Since studies show that serum ACPA decreases only slightly but statistically significantly after treatment ${ }^{15,30,31}$, the absence of ACPA-2 as determined any time during the disease course may be a reliable predictor of minimal radiographic progression in RA. In summary, therefore, the presence of ACPA-2, but not its titer, at baseline can be a predictor of radiographic progression or 


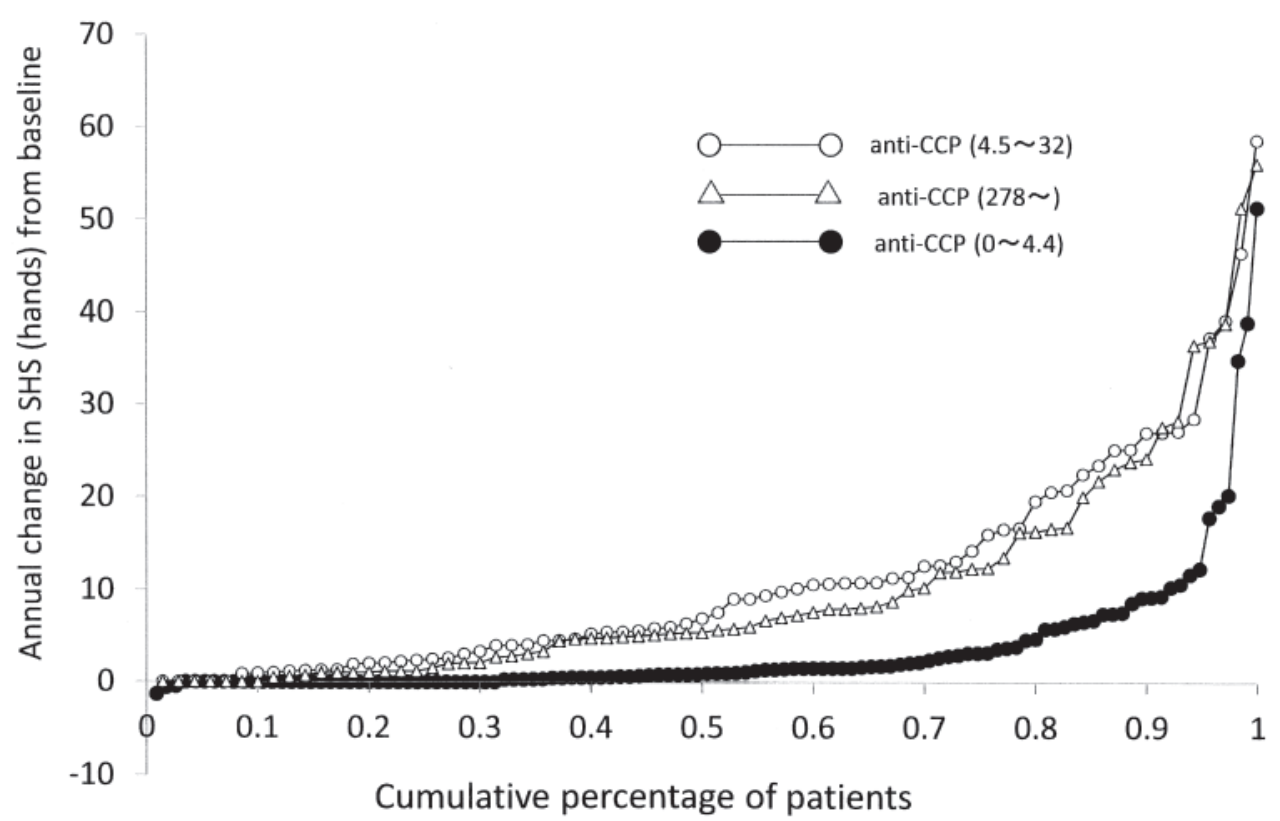

Figure 3. Cumulative probability plot shows annual change in van der Heijde-modified Sharp score (SHS) of hands from baseline, for ACPA-2 titer in patients with the ACPA-2 lowest-positive quartile (4.5-32) and highest-positive quartile (> 278) in comparison to ACPA-2-negative $(<4.5)$ patients.

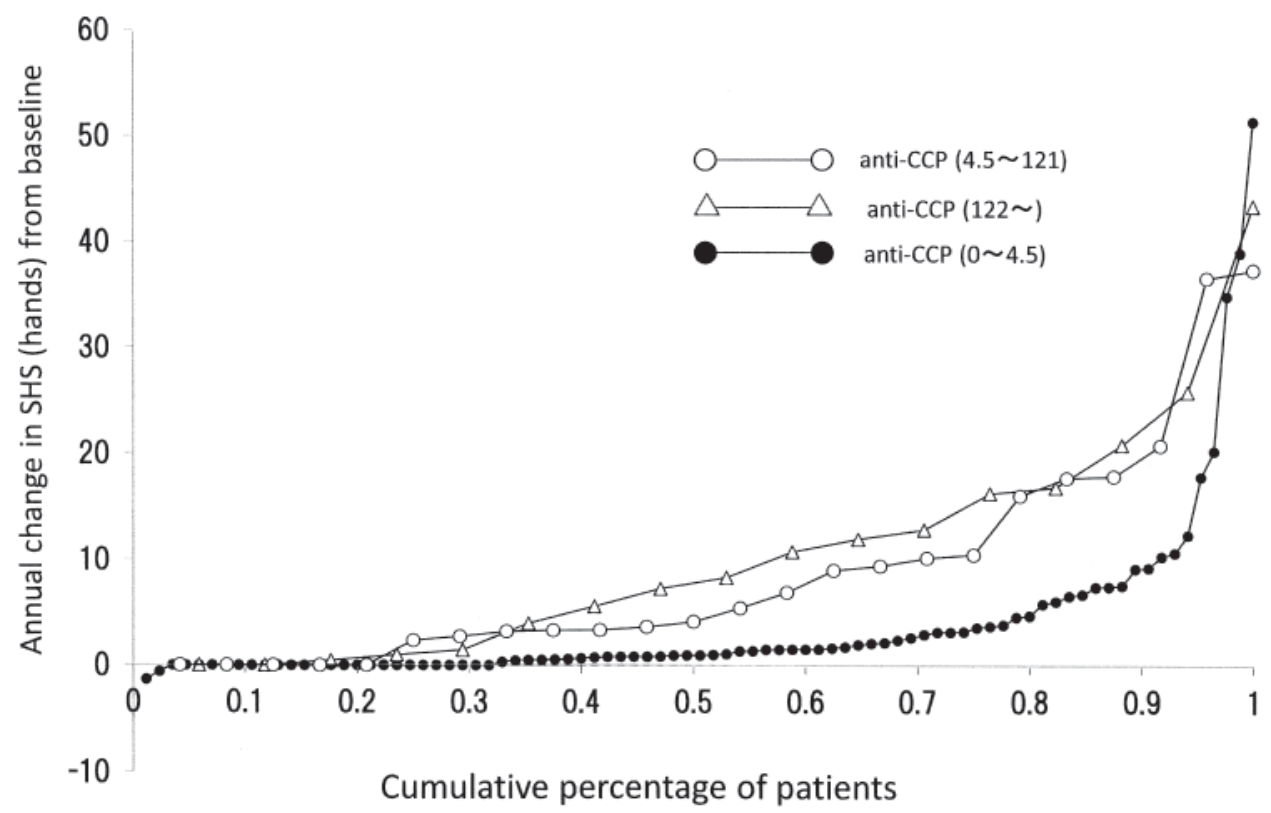

Figure 4. Cumulative probability plot shows annual change in van der Heijde-modified Sharp score (SHS) of hands from baseline, for ACPA-2 titer in patients who were negative for rheumatoid factor $(n=126)$.

disease activity. In particular, we may conclude that radiographic progression is minimal in ACPA-2-negative patients, whereas it is not predictable whether radiographic progression is always faster in ACPA-2-positive patients.

\section{ACKNOWLEDGMENT}

We thank Takahiro Makishita, $\mathrm{PhD}$, and Naoki Akamatsu, $\mathrm{PhD}$, for critically reviewing the manuscript and helping in statistical evaluation of the results.

\section{REFERENCES}

1. Szodoray P, Szabo Z, Kapitany A, Gyetvai A, Lakos G, Szanto S, et al. Anti-citrullinated protein/peptide autoantibodies in association with genetic and environmental factors as indicators of disease outcome in rheumatoid arthritis. Autoimmun Rev 2010;9:140-3.

2. van der Linden MP, van der Woude D, Ioan-Facsinay A, Levarht EW, Stoeken-Rijsbergen G, Huizinga TW, et al. Value of anti-modified citrullinated vimentin and third-generation anti-cyclic citrullinated peptide compared with second-generation anti-cyclic 
citrullinated peptide and rheumatoid factor in predicting disease outcome in undifferentiated arthritis and rheumatoid arthritis. Arthritis Rheum 2009;60:2232-41.

3. Yamane T, Hashiramoto A, Tanaka Y, Tsumiyama K, Miura Y, Shiozawa K, et al. Easy and accurate diagnosis of rheumatoid arthritis using anti-cyclic citrullinated peptide 2 antibody, swollen joint count, and C-reactive protein/rheumatoid factor. J Rheumatol 2008;35:414-20.

4. Kroot EJ, de Jong BA, van Leeuwen MA, Swinkels H, van den Hoogen FH, van 't Hof M, et al. The prognostic value of anti-cyclic citrullinated peptide antibody in patients with recent-onset rheumatoid arthritis. Arthritis Rheum 2000;43:1831-5.

5. Vencovsky J, Machacek S, Sedova L, Kafkova J, Gatterova $\mathrm{J}$, Pesalova V, et al. Autoantibodies can be prognostic markers of an erosive disease in early rheumatoid arthritis. Ann Rheum Dis 2003;62:427-30.

6. Forslind K, Ahlmen M, Eberhardt K, Hafstrom I, Svensson B, for the BARFOT study group. Prediction of radiological outcome in early rheumatoid arthritis in clinical practice: Role of antibodies to citrullinated peptides (anti-CP). Ann Rheum Dis 2004;63:1090-5.

7. Meyer O, Labarre C, Dougados M, Goupille Ph, Cantagrel A, Dubois A, et al. Anticitrullinated protein/peptide antibody assays in early rheumatoid arthritis for predicting five year radiographic damage. Ann Rheum Dis 2003;62:120-6.

8. De Rycke L, Peene I, Hoffman IE, Kruithof E, Union A, Meheus L, et al. Rheumatoid factor and anticitrullinated protein antibodies in rheumatoid arthritis: diagnostic value, associations with radiological progression rate, and extra-articular manifestations. Ann Rheum Dis 2004;63:1587-93.

9. Nell VP, Machold KP, Stamm TA, Eberl G, Heinzl H, Uffmann M, et al. Autoantibody profiling as early diagnostic and prognostic tool for rheumatoid arthritis. Ann Rheum Dis 2005;64:1731-6.

10. Lindqvist E, Eberhardt K, Bendtzen K, Heinegard D, Saxne T. Prognostic laboratory markers of joint damage in rheumatoid arthritis. Ann Rheum Dis 2005;64:196-201.

11. Nell-Duxneuner V, Machold K, Stamm T, Eberl G, Heizl H, Hoefler E, et al. Autoantibody profiling in patients with very early rheumatoid arthritis: A follow-up study. Ann Rheum Dis 2010;69:169-74.

12. Nieto-Colonia AM, Santos WS, Keusseyan SP, Caldana W, Fernandes AR, Andrade LE. Antibodies to citrullinated peptides are not associated with the rate of joint destruction in patients with a well-established diagnosis of rheumatoid arthritis. Braz J Med Biol Res 2008;41:188-92.

13. van der Helm-van Mil AH, Verpoort KN, Breeveld FC, Toes RE, Huizinga TW. Antibodies to citrullinated proteins and differences in clinical progression of rheumatoid arthritis. Arthritis Res Ther 2005;7:R949-58

14. Kastbom A, Strandberg G, Lindroos A, Skogh T. Anti-CCP antibody test predicts the disease course during 3 years in early rheumatoid arthritis (the Swedish TIRA project). Ann Rheum Dis 2004;63:1085-9.

15. Ronnelid J, Wick MC, Lampa J, Lindblad S, Nordmark B, Klareskog L, et al. Longitudinal analysis of citrullinated protein/peptide antibodies (anti-CP) during 5 year follow up in early rheumatoid arthritis: Anti-CP status predicts worse disease activity and greater radiological progression. Ann Rheum Dis 2005;64:1744-9.

16. Aletaha D, Neogi T, Silman A, Funovits J, Felson DT, Bingham CO 3rd, et al. 2010 rheumatoid arthritis classification criteria: An American College of Rheumatology/European League Against Rheumatism collaborative initiative. Ann Rheum Dis 2010;69:1580-8.
17. Gossec L, Dougados M, Goupille P, Cantagrel A, Sibilia J, Meyer $\mathrm{O}$, et al. Prognostic factors for remission in early rheumatoid arthritis: A multiparameter prospective study. Ann Rheum Dis 2004;63:675-80.

18. Miriovsky BJ, Michaud K, Thiele GM, O’Dell JR, Cannon GW, Kerr G, et al. Anti-CCP antibody and rheumatoid factor concentrations predict greater disease activity in men with rheumatoid arthritis. Ann Rheum Dis 2010;69:1292-7.

19. Meyer O, Nicaise-Roland P, dos Santos M, Labarre C, Dougados M, Goupille P, et al. Serial determination of cyclic citrullinated peptide autoantibodies predicted five-year radiological outcomes in a prospective cohort of patients with early rheumatoid arthritis. Arthritis Res Ther 2006;8:R40.

20. Syversen SW, Gaarder PI, Goll GL, Odegard S, Haavardsholm EA, Mowinckel P, et al. High anti-cyclic citrullinated peptide levels and an algorithm of four variables predict radiographic progression in patients with rheumatoid arthritis: Results from a 10-year longitudinal study. Ann Rheum Dis 2008;67:212-7.

21. Quinn MA, Gough KS, Green MJ, Devlin J, Hensor EMA, Greenstein A, et al. Anti-CCP antibodies measured at disease onset help identify seronegative rheumatoid arthritis and predict radiological and functional outcome. Rheumatology 2005;45:478-80.

22. Reneses S, Gonzalez-Escribano MF, Fernandez-Suarez A, Pestana L, Davila B, Wichmann I, et al. The value of HLA-DRB1 shared epitope, -308 tumor necrosis factor-alpha gene promoter polymorphism, rheumatoid factor, anti-citrullinated peptide antibodies, and early erosions for predicting radiological outcome in recent-onset rheumatoid arthritis. J Rheumatol 2009;36:1143-9.

23. Ursum J, Bos WH, van Dillen N, Dijkmans BA, van Schaardenburg D. Levels of anti-citrullinated protein antibodies and $\operatorname{IgM}$ rheumatoid factor are not associated with outcome in early arthritis patients: A cohort study. Arthritis Res Ther 2010;12:R8.

24. Arnett FC, Edworthy SM, Bloch DA, McShane DJ, Fries JF, Cooper NS, et al. The American Rheumatism Association 1987 revised criteria for the classification of rheumatoid arthritis. Arthritis Rheum 1988;31:315-24.

25. van der Heijde D. How to read radiographs according to the Sharp/van der Heijde method. J Rheumatol 2000;27:261-3.

26. Farragher TM, Lunt M, Plant D, Bunn DK, Barton A, Symmons DP. Benefit of early treatment in inflammatory polyarthritis patients with anti-cyclic citrullinated peptide antibodies versus those without antibodies. Arthritis Care Res 2010;62:664-75.

27. Aikawa Y, Morimoto K, Yamamoto T, Chaki H, Hashiramoto A, Narita H, et al. Treatment of arthritis with a selective inhibitor of c-Fos/activator protein-1. Nat Biotechnol 2008;26:817-23.

28. Shiozawa $S$, Tsumiyama K. Pathogenesis of rheumatoid arthritis and c-Fos/AP-1. Cell Cycle 2009;8:1539-43.

29. Shiozawa S, Tsumiyama K, Yoshida K, Hashiramoto A Pathogenesis of joint destruction in rheumatoid arthritis. Arch Immunol Ther Exp 2011;59:89-95.

30. Alessandri C, Bombardieri M, Papa N, Cinquini M, Magrini L, Tincani A, et al. Decrease of anti-cyclic citrullinated peptide antibodies and rheumatoid factor following anti-TNF therapy (infliximab) in rheumatoid arthritis is associated with clinical improvement. Ann Rheum Dis 2004;63:1218-21.

31. Mikuls TR, O'Dell JR, Stoner JA, Parrish LA, Arend WP, Norris $\mathrm{JM}$, et al. Association of rheumatoid arthritis treatment response and disease duration with declines in serum levels of IgM rheumatoid factor and anti-cyclic citrullinated peptide antibody. Arthritis Rheum 2004;50:3776-82. 